удК 347.426 .6

DOI https://doi.org/10.32837/yuv.v0i5.2250

Ю. Жегулін,

адвокат, провідний юрисконсульт відділу представництва

в судових та виконавчих провадженнях

Управління з питань стягнення шкоди

Фонду гарантування вкладів фізичних осіб

\title{
НОВИЙ ПОГЛЯД НА ДЕЛІКТ. ТЕОРЕТИЧНІ ТА ПРАКТИЧНІ ПРОБЛЕМИ ІНСТИТУТУ ДЕЛІКТНОЇ ВІДПОВІДАЛЬНОСТІ
}

Дотепер у правовій науці не існує єдиного доктринального розуміння правової суті поняття цивільної відповідальності та чіткого розумінняпідстав цієї відповідальності, що породжує значні дискусії, зокрема, і щодо такого виду цієї відповідальності, як деліктна.

Станом натепер домінуючою $€$ точка зору науковців (зокрема, С.С. Алексєєва [1], М.М. Агаркова [2], В.Т. Смірнова, А.А. Собчака [3] та інших), які розглядають цивільну відповідальність як санкцію за цивільне правопорушення, а єдиною підставою для ії виникнення називають наявність складу цивільного правопорушення (різні автори пропонують різні варіанти складу цивільного правопорушення). Сама концепція складу правопорушення більш детально і повно була розроблена в науці кримінального права і саме з кримінального права була запозичена для пояснення та описання підстав відповідальності цивільної. Існує думка, що «склад правопорушення» як інститут (або як певний правовий механізм) має звичаєве, загальнотеоретичне значення і з певною специфікою застосовується в усіх галузях права.

Вітчизняна судова практика в деліктних спорах уже досить тривалий час будується саме на необхідності встановлення складу цивільного правопорушення як єдиної умови для притягнення особи до відповідальності за заподіяння шкоди. До прикладу, в межах справ № 905/2191/15, № 686/11256/16-ц та багатьох інших Верховний Суд вчергове вказав, що стягнення збитків є одним із видів цивільно-правової відповідальності, для застосування якого потрібна наявність усіх елементів складу цивільного правопорушення, a саме: протиправної поведінки, збитків, причинного зв'язку між протиправною поведінкою боржника та збитками й вини.Наявність перших трьох із числа зазначених елементів доводиться особою, яка звернулася з вимогою про відшкодування збитків. Вина презюмується, а іï відсутність доводиться заподіювачем шкоди. За відсутності хоча б одного з цих елементів цивільна відповідальність не настає.

Як можна побачити, в основу поточної правозастосовчої практики та теорії, на якій вона будується, покладено одразу декілька правових концепцій:

1. Стягнення збитків є санкцією за цивільне правопорушення;

2. 3 попереднього твердження витікає, що єдиною підставою для притягнення особи до відповідальності $€$ факт вчинення цією особою цивільного правопорушення (nullapoenasinelege).

3. Задля встановлення факту вчинення особою цивільного правопору- 
шення необхідно встановити наявність в іiі діях усіх елементів складу цивільного правопорушення. Серед запропонованих науковцями варіантів складу цивільного правопорушення для застосування було вибрано варіант, запропонований M.M. Агарковим (шкода, протиправність, причинний зв'язок і вина).

Разом із цим існують вагомі підстави вважати такий підхід помилковим, оскільки він суперечить описаним у законодавстві деліктним правовідносинам, іншим загальновизнаним правовим концепціям та має негативний плив на правозастосовчу практику і розвиток інституту деліктної відповідальності в цілому.

Інша група науковців, зокрема, O.В. Кузьменко [4], М.I. Брагінський, В.В. Вітрянський [5], Г.Ф. Шершеневич [6] та інші, вказують на те, що поняття «складу правопорушення» не має практичного значення в цивілістиці і $€$ штучно привнесеним із кримінального права. До прикладу, Г.Ф. Шершеневич указує на те, що цивільна відповідальність будується на інших засадах, ніж кримінальна. Покарання передбачає неодмінну наявність злочину: без кримінального правопорушення не існує кримінальної відповідальності (nullapoenasinecrimine). Навпаки, цивільна відповідальність іноді може встановлюватись поза межами цивільного правопорушення. Закон може покласти на особу відповідальність за майнову шкоду без будь-якої вини або навітьбільше, за умови, коли ця особа не завдавала жодної шкоди. Цивільна відповідальність виражається у винагороді за шкоду, яку винний завдав потерпілому. Винагороду за шкоду не слід змішувати 3 майновим покаранням, оскільки на відміну від покарання, яке вимірюється ступенем злочинної волі, винагорода за шкоду визначається майновим станом потерпілого (прим. авт. - мається на увазі розміром заподіяної шкоди). М.I. Бра- гінський та В.В. Вітрянський слушно вказують, що підставою цивільно-правової відповідальності є порушення суб'єктивних цивільних прав, як майнових, так і особистих немайнових, оскільки цивільно-правова відповідальність є відповідальністю одного учасника майнового обороту перед іншим, а іiі загальною метою $€$ відновлення порушеного права на основі принципу відповідності розміру відповідальності розміру заподіяної шкоди або збитків. Також абсолютно вірно відзначено, що під час застосування цивільно-правової відповідальності не мають жодного правового значення «шкідливі наслідки» 3 точки зору негативного впливу допущеного порушення цивільних прав на суспільні інтереси, «об'єктивна» i «суб'єктивна» сторони цивільного правопорушення.

Розвиваючи ці твердження, nepue, на що варто звернути увагу, це те, що склад цивільного правопорушення «не вписується» в існуючі деліктні правовідносини, тобто не проходить перевірки практикою.

Зокрема, законодавством передбачено ряд випадків, коли відбувається «притягнення до відповідальності» за шкоду, завдану правомірними діями.

До таких випадків відносяться:

- відшкодування шкоди, завданої в стані крайньої необхідності (ч. 1 ст. 1171 ЦК України);

- відшкодування шкоди, завданої реквізицією майна (ст. 353 ЦК України);

- відшкодування шкоди, завданої в результаті прийняття закону про припинення права власності на певне майно (ст. 1170 ЦК України);

- відшкодування шкоди, завданої особою в разі здійснення нею права на самозахист (ч. 2 ст. 1169 ЦК України):

- відшкодування шкоди, завданої в результаті загальної аварії (ст. 277 Кодекс торговельного мореплавства України). 
У перелічених вище випадках виходить, що особа притягується до відповідальності не просто за відсутності в іï діях повного складу цивільного правопорушення, а за відсутності правопорушення як такого. Г.К. Матвєєв слушно зазначав із цього приводу таке. Якщо дії не є протиправними, то вони є правомірними, а за правомірні діi особа не може та не повинна притягуватися до відповідальності, в т.ч. і до цивільно-правової [7].

Крім того, законодавство передбачає цілу низку випадків, коли заподіяння шкоди, хоча і вважається протиправним, проте до відповідальності за цю шкоду притягується особа, в діях якої відсутні всі або частина елементів складу цивільного правопорушення. Тобто відповідальність покладається на осіб, які не завдавали шкоди, або за відсутності вини цих осіб. Г.К. Матвєєв називає таку відповідальність «безпричинною» та «безвинною», хоча, на його думку, використання таких термінів $€$ некоректним.

До «безпричинної» відповідальності можна віднести, зокрема:

- відшкодування шкоди, завданої джерелом підвищеної небезпеки (ст. 1187 ЦК України). Підставою для покладення відповідальності є лише факт наявності права власності на майно, що $є$ джерелом підвищеної небезпеки;

- відшкодування шкоди, завданої в стані крайньої необхідності, особою, в інтересах якої діяла особа, яка завдала шкоди (ч. 2 ст. 1171 ЦК України);

- покладання відповідальності за шкоду, заподіяну внаслідок реалізаціï права на самозахист, на особу, яка вчинила протиправне посягання (ч. 2 ст. 1169 ЦК України). У цьому випадку відсутній причинно-наслідковий зв'язок між протиправним посяганням та заподіяною шкодою;

- відшкодування юридичною або фізичною особою шкоди, завданої їхнім працівником чи іншою особою (підрядником, що діяв за завданням замовника; учасником товариства або членом кооперативу, які діяли від імені товариства/кооперативу) (ст. 1172 ЦК України);

- відшкодування шкоди, завданої малолітньою особою, іï батьками або опікуном чи іншою фізичною особою, яка на правових підставах здійснює виховання малолітньої особи, якщо вони не доведуть, що шкода не $€$ наслідком несумлінного здійснення або ухилення ними від здійснення виховання та нагляду за малолітньою особою (ст. 1178 ЦК України). Тобто батьки, опікуни чи інші особи, що здійснюють виховання, не $€$ завдавачами шкоди, натомість закон встановлює презумпцію здійснення ними несумлінного виховання і виключно на цій підставі покладає відповідальність за збитки;

- відшкодування шкоди, завданої неповнолітньою особою, іiі батьками (усиновлювачами) або піклувальником у разі відсутності в неповнолітньої особи майна, достатнього для відшкодування завданої нею шкоди, та якщо вони не доведуть, що шкоди було завдано не з їхньої вини (ч. 2 ст. 1179 ЦК України та 1180 ЦК України). Батьки (усиновлювачі) або піклувальники так само не є завдавачами шкоди, а підставою покладення на них відповідальності закон визначає відсутність у неповнолітньої особи майна, достатнього для відшкодування завданої шкоди, так виглядає та сама презумпція несумлінного виховання (на це вказує коментар до ЦК, і це $є$ логічним, хоча в самій нормі про це не згадується);

- відшкодування шкоди батьками, позбавленими батьківських прав, протягом трьох років після позбавлення їх батьківських прав (ч. 2 ст. 1183 ЦК України);

- відшкодування шкоди, завданої недієздатною фізичною особою, іiі опікуном або закладом, який зобов'я- 
заний здійснювати нагляд за нею (ст. 1184 ЦК України).

До «безвинної відповідальності» (коли відшкодування відбувається незалежно від наявності вини деліквента) можна віднести:

- відшкодування шкоди, завданої органом державної влади, органом влади Автономної Республіки Крим або органом місцевого самоврядування (ст. 1173 ЦК України);

- відшкодування шкоди, завданої посадовою або службовою особою органу державної влади, органу влади Автономної Республіки Крим або органу місцевого самоврядування (ст. 1174 ЦК України).

Вищенаведені приклади з усією наочністю демонструють, що концепція визначення відшкодування шкоди як санкції за цивільне правопорушення та визначення складу цивільного правопорушення як єдиної підстави для такої відповідальності не здатні адекватно описати існуючі деліктні правовідносини та породжують суттєві протиріччя. Виникають серйозні питання щодо справедливості, ефективності та конституційності застосування до особи покарання за правомірні дії або за відсутності вини особи в заподіянні шкоди, або за дії інших осіб. Застосування до особи санкції за цивільне правопорушення за вищевказаних умов $є$ прямим порушенням принципу nullapoenasinelege.

Так само концепція складу цивільного правопорушення не узгоджується 3 принципом генерального делікту та зі спеціальними деліктами.

Принцип генерального делікту $€$ загальновідомим та загальновизнаним у правовій науці. Вважається, що цей принцип отримав найбільш повне вираження в ст. 1382 Цивільного кодексу Франції (Кодексу Наполеона): «будь-яка дія людини, яка заподіює шкоду іншій, зобов'язує того, з вини кого ця шкода настала, до відшкодування збитків» [8]. Згідно з цим принципом кожне завдання шкоди іншій особі вважається протиправним, поки не буде встановлено інше [9]. Варто вказати, що застосування принципу генерального делікту знайшло своє відображення і в рішеннях Верховного Суду, зокрема, в межах справ № $212 / 7779 / 17$ та № 210/4091/17 суд зазначив таке: "порушення законних прав, указаних у законі осіб, завжди є протиправним. <..> У статті 440-1 ЦК Української РСР виявляється дія принцииу генерального делікту, закріпленого в статті 440 ЦК Української РСР, в силу якого заподіяння шкоди признається протиправним, якщо особа не була уповноважена на $\dddot{i}$ заподіяння».

Суперечність концепції складу цивільного правопорушення і принципу генерального делікту полягає в тому, що склад цивільного правопорушення визначає одним зі своїх елементів, який підлягає обов'язковому з'ясуванню і доведенню, протиправну поведінку заподіювача шкоди, тоді як принцип генерального делікту будь-яке заподіяння шкоди визначає протиправним (презумпція протиправності заподіяння шкоди). Власне, виникає закономірне питання щодо того, чи потрібно позивачу в деліктних спорах доводити протиправність заподіяння йому шкоди, чи ця протиправність презюмується. Станом натепер у спорах про відшкодування шкоди суди, як уже згадувалось, вимагають від постраждалої сторони довести протиправність поведінки заподіювача шкоди, що видається помилковим. Фактично на постраждалу особу покладається обов'язок доводити, що заподіяння їй шкоди є недозволеною дією, хоча цілком очевидно, що за звичайних обставин заподіяння шкоди не може вважатись чимось законним чи нормальним. Шкода за своєю правовою природою $€$ порушенням майнових чи особистих немайнових прав абсолютного характеру (право на життя 
та здоров'я, честь та гідність, право власності та інші речові права) потерпілої особи, тобто є протиправною апріорі. Описані вище в цій статті випадки правомірного заподіяння шкоди $€$ виключенням iз загального правила i ïx перелік $€$ вичерпним, що у свою чергу вказує на протиправність заподіяння шкоди в усіх інших випадках, коли закон не визначив таке заподіяння шкоди законним.

Поряд із генеральним деліктом, який встановлює загальні умови відповідальності за завдання шкоди, законодавство визначає окремі (спеціальні) делікти, які становлять винятки із загального правила та регулюються інакше, зважаючи на їх специфіку. Наведені вище приклади правомірної, «безвинної» та «безпричинної» шкоди $є$ спеціальними деліктами, і, як уже зазначалось, ці делікти входять у жорсткий конфлікт із концепцією складу цивільного правопорушення. Варто також звернути увагу на те, що спеціальні делікти можуть передбачати залучення до правовідносин між деліквентом та постраждалою особою третьої сторони, на яку повністю або частково буде покладатись додаткова відповідальність за заподіяну шкоду або повністю перекладатись обов'язок деліквента відшкодувати заподіяну шкоду. Концепція складу цивільного правопорушення просто не підходить для описання більшості спеціальних деліктів.

Все вищенаведене вказує на те, що визначення відшкодування шкоди як санкції за цивільне правопорушення, а також визначення складу цивільного правопорушення як підстави для такої відповідальності є помилковими. Згідно 3 п. 3 ч. 2 ст. 11 ЦК України, завдання майнової (матеріальної) та моральної шкоди іншій особі є підставою виникнення саме цивільних прав та обов'язків між учасниками цивільного обороту, а не підставою для покарання будь-кого.
Таким чином, стягнення шкоди за своєю правовою суттю $є$ звичайним цивільним зобов'язанням (таким же, як і будь-яке інше договірне чи позадоговірне зобов'язання), а не санкцією (покаранням) за цивільне правопорушення. Ототожнювати цивільне зобов'язання 3 покаранням недопустимо. Цивільна відповідальність $€$ відмінною від інших видів юридичної відповідальності і, як вірно вказали M.I. Брагінський та В.В. Вітрянський, за своєю суттю є відповідальністю одного учасника майнового обороту перед іншим [5]. Іншими словами, термін «цивільна відповідальність», який уживається в теорії та в законодавстві, не $є$ синонімом «санкції за правопорушення». Метою відшкодування шкоди, як вірно відзначали M.I. Брагінський, В.В. Вітрянський, Г.Ф. Шершеневич та інші, є виключно відновлення порушеного права потерпілої особи, а не покарання завдавача шкоди (тим більше, коли обов'язок відшкодування шкоди перекладається 3 деліквента на іншу особу). Підставою для покладення на особу цивільної відповідальності за заподіяну шкоду є сам факт заподіяння іншій особі шкоди та необхідність поновлення порушених прав. Саме тому розмір цієі відповідальності визначається не ступенем злочинної волі чи суспільною небезпечністю заподіяння шкоди, а виключно розміром шкоди. Оцінка дій деліквента (форма вини, спосіб та засоби заподіяння шкоди тощо) з точки зору цивільного права не має значення та не впливає на обов'язок особи відшкодувати заподіяну шкоду чи на розмір відповідальності цієї особи.

3 цієї точки зору деліктні правовідносини як позадоговірне цивільне зобов'язання досить повно описуються концепцію генерального та спеціальних деліктів, відповідно до якого, за загальним правилом, заподіяння шкоди створює цивільне зобов'язання для особи, з вини якої ця шкода настала, з іï відшкодування, 
а будь-які виключення із цього правила є спеціальними деліктами і регулюються Законом окремо.

Також необхідно вказати на негативний вплив застосування концепції складу цивільного правопорушення на правозастосовчу практику та на розвиток інституту деліктних правовідносин загалом.

Як уже зазначалось, категорія складу правопорушення була запозичена із кримінального права. Разом із цим правовідносини, що формуються в кримінальному процесі, $€$ абсолютно відмінними від цивільних правовідносин, тому застосування правових інститутів кримінального права в цивільному праві $€$ нехарактерним і створює певні проблеми. Так, у кримінальному процесі обов'язок доказування наявності в діях особи всіх елементів складу злочину покладається на сторону обвинувачення. Діючи за аналогією $з$ кримінальним процесом, суди покладають обов'язок доведення всіх елементів складу цивільного правопорушення, крім вини, на Позивача, що фактично перекладає весь тягар доказування на Позивача та створює для Відповідачів у цих справах певний аналог «презумпції невинуватості». Вбачається, що подібна практика $€$ результатом саме того, що відшкодування шкоди розглядають як певний вид покарання, а не як цивільне зобов'язання, відповідно, до позивача висуваються вимоги не тільки щодо доведення обставин справи, а й шодо доведення достатності підстав для притягнення відповідача до відповідальності (наявності складу цивільного правопорушення). Натомість цивільне та господарське процесуальне законодавство визначає обов'язок учасників спору доводити виключно фактичні обставини справи (більше того, цей обов'язок покладається на всіх учасників справи, а не тільки на позивача). Доведення наявності підстав для притягнення особи до відповідальності є характерним для кримінального та адміністративного процесів, а не для цивільного чи господарського. Цікаво, що, притягаючи осіб до адміністративної відповідальності, суди не встановлюють усіх елементів складу адміністративного правопорушення, хоча судова практика визначає склад адміністративного правопорушення як єдину підставу для притягнення правопорушника до відповідальності (Постанова Верховного Суду від 19 лютого 2020 року у справі № 204/8036/16-а). Натомість, стягуючи шкоду, суди висувають жорсткі вимоги до Позивача щодо доведення наявності в діях Відповідача складу цивільного правопорушення.

У цьому ключі необхідно звернути увагу й на позитивні приклади судової практики щодо стягнення заподіяної шкоди. Так, у справі № 920/715/17 Велика Палата Верховного Суду вказала, що суд має самостійно встановлювати наявність чи відсутність складу цивільного правопорушення, який став підставою для стягнення шкоди, оцінюючи виключно надані сторонами докази. Наведена правова позиція Верховного Суду в значній мірі виправляє дисбаланс розподілу обов'язків доказування між сторонами спору в справах про відшкодування шкоди та знімає з Позивачів обов'язок доводити наявність складу цивільного правопорушення. Разом із цим значна кількість вищеописаних протиріч у деліктних правовідносинах залишаються невирішеними. До прикладу, проблемним залишається питання доведення наявності складу цивільного правопорушення в діях осіб, на яких $з$ деліквента перекладається відповідальність за заподіяну шкоду, для застосування до цих осіб «санкцій за цивільне правопорушення» (спеціальні делікти).

3 точки зору правової науки, закріплення концепції складу цивільного правопорушення на рівні правозастосовчої практики призводить до зміщення акценту на дослідження виключно складу цивільного правопорушення. Станом натепер доктрина 
генерального та спеціальних деліктів у судовій практиці майже не використовується (поодинокі приклади iii використання лише підтверджують цей висновок), а науковці, хоча й визнають існування цього правового інституту, проте не приділяють йому значної уваги. Деякі вітчизняні науковці, наприклад Т.С. Ківалова [10], В.В. Міщук [11], Н.Ю. Голубєва [12], намагаються суміщати доктрину генерального та спеціальних деліктів з доктриною цивільного правопорушення або гармонізувати ці доктрини, пропонуючи спеціальні склади правопорушення для спеціальних деліктів, проте подібне об'єднання виглядає штучним та не вирішує описаних вище фундаментальних протиріч.

Таким чином, існує нагальна потреба змінити традиційні для вітчизняної науки підходи до визначення правової природи деліктних правовідносин і насамперед змінити правозастосовчу практику в спорах про відшкодування шкоди. Варто визнати, що радянське розуміння суті цивільних правовідносин через призму «злочин - покарання» $є$ анахронізмом і не відповідає сучасному рівню розвитку українського суспільства і проголошеним стандартам захисту особи та іiі власності. Йдеться не тільки про переосмислення теоретичних основ інституту деліктної відповідальності, a i про встановлення нового, більш високого стандарту захисту прав осіб, яким було заподіяно шкоду.

У cmammi розглянуто та проаналізовано існуючі вітчизняні правові концепиіï, щзо описують інститут деліктної відповідальності, проаналізовано поточну судову практику в спорах про відшкодування шкоди, а також виділено та проаналізовано низку проблемних питань теорії та практики в uүiŭ категоріï спорів. Автор наполягає на помилковості домінуючої сьогодні наукової точки зору, яка визначає обов'язок з відикодування шкоди як санкцію за ц̧ивільне правопорушення $i$ вказуе на необхідність установлення складу ицивільного правопорушення як єдиної можливої підстави для стягнення заподіяної шкоди. На прикладах відшкодування правомірно заподіяної икоди, «безпричинної» та «безвинної» відповідальності за шкоду, а також на численних прикладах інших спеціальних деліктів, було продемонстровано хибність концепції складу циивільного правопорушення. Проведений аналіз також показав несумісність концепції складу циивільного правопорушення, яка використовується українськими судами, та принuзипу генерального делікту, який $\epsilon$ загальновідомим $i$ який так само застосовується в судовій практиці. Також автором зроблено короткий огляд спроб украінських науковиів об’єднати концеепцію генерального делікту та кониепиію складу ициільного правопорушення. у статті доведено необхідність розглядати деліктну відповідальність як один із видів циивільного зобов'язання, що виникае на підставі самого факту заподіяння особі шкоди з вини іншої особи, а не як покарання за правопорушення. Розкривається суть приниципу генерального та спеціальних деліктів як достатньої теоретичної основи для описання всіх видів деліктних зобов'язань. Крім того, аналізується негативний вплив існуючої правозастосовчої практики у спорах з відшкодування шкоди на права потерпілої особи та на розвиток правової науки.

Ключові слова: делікт, деліктні правовідносини, правомірна шкода, безпричинна відповідальність за шкоду, безвинна відповідальність за шкоду, генеральний делікт, спеціальний делікт, цивільне правопорушення, склад цивільного правопорушення, цивільна відповідальність. 
Zhegulin Yu. A new view on tort. Theoretical and practical problems of the institute of tort responsibility

The article considers and analyzes the existing legal concepts that describe the institution of tort liability in Ukraine, analyzes the current case law in disputes over damages, as well as identifies and analyzes a number of problematic issues of theory and practice in this category of disputes. The author insists on the fallacy of the prevailing scientific view, which defines the obligation to compensate for damage as a sanction for a civil offense, and the need to establish the composition of a civil offense as the only possible basis for recovery. By using the examples of compensation for lawfully caused damage, "causeless" liability for damage and liability for damage without guilt, as well as numerous examples of other special torts, it was demonstrated the failing of the concept of the composition of a civil offense. An analysis also showed the incompatibility of the concept of the composition of a civil offense used by Ukrainian courts and the principle of general tort, which is well known and which is also applied in judicial practice. The author also gave a brief overview of the attempts of Ukrainian scholars to combine the concept of a general tort and the concept of the composition of a civil offense. The article proves that tortious liability should be considered as one of the types of civil obligation arising from the very fact of causing harm to a person through the fault of another person, and not as a punishment for an offense. The essence of the principle of general and special torts is revealed as a sufficient theoretical basis for describing all types of torts. In addition, the negative impact of existing law enforcement practices in disputes on damages on the rights of the victim and on the development of legal science is analyzed.
Key words: delict, tort, tort legal relations, lawful damage, causeless liability for damage, liability for damage without guilt, general tort, special tort, civil offense, composition of civil offense, civil liability.

\section{Література}

1. Алексеев С.С. Проблемы теории права. Свердловск, 1972. Т. 1. С. 377-382.

2. Агарков М.М. Обязательство по советскому гражданскому праву. Москва, 1940. C. 44.

3. Смирнов B.T., Собчак А.А. Общие учения о деликтных обязательствах в советском гражданском праве. Ленинград, 1983. С. 56.

4. Кузьменко О.В. Відповідальність за шкоду, заподіяну джерелом підвищеної небезпеки в українській та російській цивілістиці Харьков, 2010. С. 248-251.

5. Брагинский М.И, Витрянский В.В. Договорное право: Общие положения. Москва : Cmamym, 1997. URL: http:/ / library.nlu.edu.ua/POLN_ TEXT / KNIGI/DOGOVOR_KN_1.htm

6. Шершеневич Г.Ф. Избранное : В $6 \mathrm{~m}$. Москва : Cmamym, 2016. T. 4: включая Общую теорию права. 752 с. С. 586-605. URL: http: / / www.consultant.ru/ edu/student / download_books / book / shershenevich_gf_izbrannoe_t4 /

7. Матвеев Г.К. Основания гражданско-правовой ответственности. Москва : Юрид. лит., 1970. С. 7-17.

8. Суханов Е.А. Цивільне право: : 4 m. 2008. T. 4: Зобов'язальне право. URL: http: / / yport.inf.ua/vozniknoveniedeliktnogo-obyazatelstvaponyatie.html; Pozau О.Я. Становлення та розвиток категорії зловживання правом у законодавстві Франuіï (XVIII-XIX столітmя). 2010 p. URL: http: / / lawreview.chnu.edu.ua / visnuku/ st $/ 550 / 5 . p d f$

9. Грін О.О. Делікти в иивільному праві України : навчальний посібник. Ужгород : Видавниитво ФОП Бреза А.Е., 2013. URL:https: / /dspace.uzhnu.edu.ua/jspui / bitstream / lib/8944 / 1 / Делікти\% 20в\% 20 цивільному\% 20праві\% 20України.рdf

10. Ківалова Т. Класифікація зобов'язань відшкодування шкоди. Юридичний вісник. 2011. № 1. С. 40-46. URL: http: / / yurvisnyk.in.ua/v1_2011/07.pdf

11. Міщук В.В. Делікт як підстава цивільно-правової відповідальності за 
шкоду, завдану джерелом підвищеної небезпеки. Університетські наукові записки : часопис ; Хмельнии. ун-т упр. та права. Хмельницький : Хмельниц. ун-т управ. та права, 2013. № 3(47). C. 146-151. C. 150-151. URL: http: / / nbuv.gov.ua/j-pdf/Unzap_ 2013_3_23.pdf
12. Голубєва Н.Ю. Загальні підстави відповідальності за завдану майнову шкоду: на матеріалах судової практики (коментар до ст. 1166 ЦК України). Наукові праці НУ ОЮА. 2015. C. 71-86. URL: http: / / dspace.onua.edu.ua / bitstream / handle / $11300 / 6487 /$ Golubeva\%20nauk\%20 pra\% 2016.pdf?sequence $=1 \&$ is Allowed $=y$

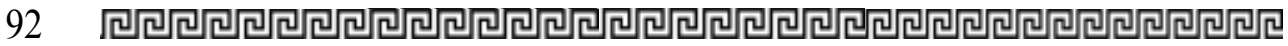

